\title{
Ali naj moj problem brezposelnosti rešujejo drugi?
}

Dušanka Lužar

\begin{abstract}
$S$ problemom hitrega naraščanja brezposelnosti smo se $v$ Sloveniji srečali v začetku devetdesetih let, ko je s prehodom $v$ tržno gospodarstvo in procesom prestrukturiranja gospodarstva naglo začela upadati tudi zaposlenost. V tem obdobju so se v podjetjih začeli stečaji, pojavili so se presežki delovne sile. V Sloveniji se je začel uveljavljati trg delovne sile.
\end{abstract}

Upadanju števila zaposlenih je sledilo naraščanje brezposelnosti. Število brezposelnih se je v letih od 1989 do 1995 povečalo za skoraj štirikrat, kar pomeni, da je bilo ob koncu leta $1995 \mathrm{v}$ Sloveniji 126.759 brezposelnih oseb.

Med zaposlenimi se je najhitreje zmanjševalo število nekvalificiranih delavcev. Tako je med brezposelnimi naraščalo število oseb brez poklicne izobrazbe. Med osebami s III. in IV. stopnjo izobrazbe prevladujejo osebe s poklici, po katerih delodajalci redko povprašujejo. Zaradi razpada velikih sistemov z delovno intenzivno naravnanostjo prihaja do strukturnih neskladij (kovinarstvo, tekstil).

Osebam z višjo stopnjo izobrazbe pa navadno primanjkuje splošno znanje oziroma kombinacija različnih vrst znanja, po katerih delodajalci vedno pogosteje povprašujejo (npr. znanje tujih jezikov, računalništvo, spretnost uspešnega poslovnega komuniciranja itd.).

Poleg velikega števila brezposelnih je na trgu dela tudi vse več delovnih mest, za katera ni mogoče najti ustreznih delavcev. Zato v Sloveniji govorimo o strukturni brezposelnosti, ki se kaže v presežkih nekaterih poklicev in v pomanjkanju drugih.

Izobraževanje brezposelnih je eden najpomembnejših ukrepov v sklopu aktivne politike zaposlovanja. Z ukrepom aktivne politike zaposlovanja razumemo vrsto instrumentov za reguliranje trga delovne sile. Razvili so jih v tržnih ekonomijah zahodne Evrope, predvsem v zadnjih dvajsetih letih.

Aktivna politika zaposlovanja je sklop ciljno usmerjenih ukrepov in programov, ki jih uresničujejo na trgu dela, ustvarjajo dodatne delovne možnosti, povečujejo poklicno, sektorsko in prostorsko mobilnost delovne sile, omogočajo prilagajanje znanja in usposobljenosti delavcev na spremenjene razmere produkcije $v$ tržni konkurenci, spodbujajo razvoj podjetništva in samozaposlovanja ter si prizadevajo za čimbolj usklajeno ponudbo in povpraševanje.

Sprememba Zakona o zaposlovanju in zavarovanju za primer brezposelnosti je leta 1991, ko so bili zakonsko opredeljeni ukrepi aktivne politike zaposlovanja, omogočila intenzivno dejavnost v zvezi z izobraževanjem brezposelnih.

Republiški Zavod za zaposlovanje je začel intenzivno izvajati aktivnosti v zvezi z izobraževanjem brezposelnih oseb s ciljem: povečati konkurenčne sposobnosti brezposelnih iskalcev zaposlitve na trgu dela $z$ dvigovanjem izobrazbene ravni ter dopolnjevanjem znanja.

Zavod iz leta v leto širi obseg in vsebine izobraževalnih pro- gramov, vključuje večje število izvajalcev programov ter sodeluje pri razvijanju novih vsebin, programov, novih metod informiranja in svetovanja brezposelnim, ki se vključujejo $v$ izobraževalne programe. Pri tem upošteva potrebe na trgu dela ter individualne interese, sposobnosti in nagnjenja posameznikov.

$\mathrm{V}$ teoriji izobraževanja kot ene izmed oblik politike zaposlovanja so splošni cilji ekonomske ali socialne narave.

Ekonomski cilji so:

- pospeševanje prilagajanja ponudbe delovne sile povpraševanju in s tem povezano odpravljanje strukturnih neskladij v delovanju trga delovne sile;

- povečevanje vrednosti človeškega kapitala in ohranjanje vrednosti človeških virov;

- izobraževanje je eden od instrumentov anticiklične politike, $\mathrm{v}$ obdobju recesije delovno silo pripravljajo na hitro in učinkovito vključevanje $\mathrm{v}$ delo med gospodarsko rastjo;

- izobraževanje (zmanjševanje odpuščanja delovne sile in povečevanje zaposlovanja) prispeva k rasti družbenega proizvoda.

Socialni cilji so:

- preprečevanje socialne marginalizacije brezposelnih in zmanjševanje socialnih problemov;

- prerazporejanje brezposelnosti med socialnimi skupinami in kraji, kjer je brezposelnost največja;

- večja produktivnost posameznikov, ki končajo izobraževanje in se zaposlijo;

- zmanjševanje psihičnih travm in malodušja pri brezposelnih, kar izboljšuje odnose v družbi.

Zavod za zaposlovanje usmerja brezposelne v različne oblike izobraževanja zaradi povečanja zaposlitvenih možnosti.

Izobraževalne programe za brezposelne združujemo v naslednje temeljne sklope:

- programi za načrtovanje poklicne poti,

- programi pomoči pri iskanju zaposlitve,

- programi psihosocialne rehabilitacije,

- programi funkcionalnega izobraževanja,

- programi za pridobitev strokovne izobrazbe,

- usposabljanje za konkretna dela pri delodajalcu.

Z različnimi oblikami skupinskega in individualnega svetovanja ter s skupinsko obravnavo se Zavod približuje cilju, da naj bi bila vsaka posameznikova vključitev v programe zaposlovanja 
opredeljena z načrtom njegove poklicne poti. To pa pomeni, da je treba brezposelne motivirati za sodelovanje pri načrtovanju poklicne poti in iskanju zaposlitve.

Program, ki omogoča posamezniku oceno lastnih zmožnosti in pripravo, da se ustrezno predstavi delodajalcem, je delavnica Poti do dela in zaposlitve. Eden osnovnih ciljev delavnice je motiviranje udeležencev za lastno reševanje problemov v zvezi $\mathrm{z}$ delom in zaposlitvijo. Dejstvo je namreč, da posamezniki prepogosto mislijo, da so za njihove probleme dolžni poskrbeti drugi, ne sprejmejo pa lastne odgovornosti za reševanje problemov.

Delavnice so kvalitetno dopolnilo posredovalnim in svetovalnim aktivnostim zavoda.

\section{Delavnica Poti do dela in zaposlitve}

Program oziroma delavnico uvrščamo med programe izobraževanja in usposabljanja, katerih osnovni cilj je povečanje možnosti za zaposlitev brezposelnih oseb oziroma povečanje njihove konkurenčnosti na trgu delovne sile. Vloge izobraževanja brezposelnih ne bi bilo upravičeno zožiti zgolj na zagotavljanje zaposlitve, prav tako je pomembno tudi zadovoljevanje drugih človekovih potreb. Zato so poleg prej omenjenih, ekonomskih in socialnih, ciljev pomembni tudi psihološki cilji. Že po imenu spada program v sklop programov pomoči brezposelnim pri iskanju zaposlitve, katerih cilj je motivirati posameznika, da tudi sam sodeluje pri iskanju zaposlitve, in ga »oborožiti« $\mathrm{z}$ znanjem za učinkovit nastop na trgu delovne sile.

Program je neverificiran, kar je med programi funkcionalnega izobraževanja pogost pojav. Ti programi nastajajo na osnovi potreb na trgu dela, v primerjavi z verificiranimi programi v zvezi s

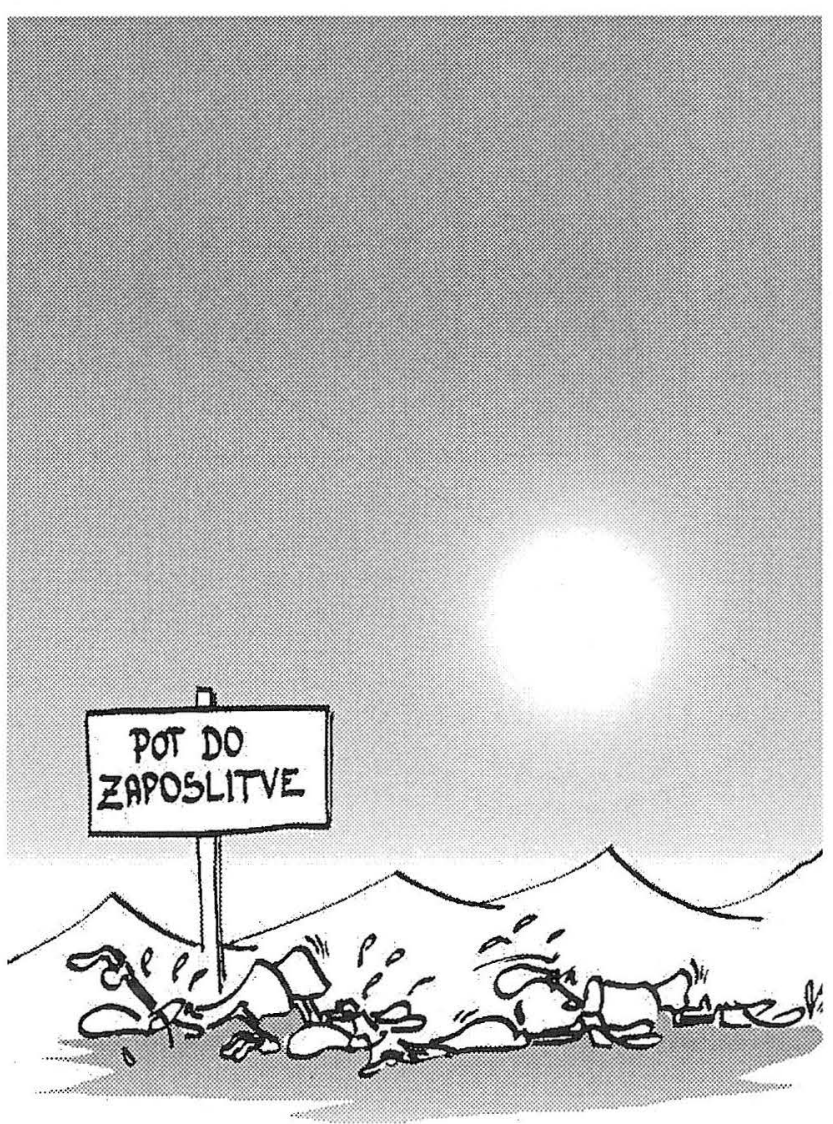

fuche96 prilagajanjem novostim je zanje značilna večja fleksibilnost. Učinkovitost teh programov se najpogosteje povezuje z aktualnostjo celotnega programa ter njegovih posameznih vsebin, kar zahteva intenzivno spremljanje dogajanja na trgu delovne sile in nenehno vnašanje novosti $\mathrm{v}$ sam program.

Za program je značilno tudi to, da spada med programe izobraževanja in usposabljanja, ki so zaradi spremenjenih razmer na trgu dela nastali na pobudo RZZ.

RZZ skrbi za uresničevanje programa in pri tem nastopa $v$ vlogi organizatorja in izvajalca monitoringa. Skrbi za nadaljnji razvoj programa, obenem pa tudi za širitev mreže izvajalcev in števila moderatorjev ter za njihovo usposabljanje.

\section{Nastanek programa}

Prehod v tržno ekonomijo, ki je zahteval korenito prestrukturiranje gospodarstva, je ob koncu devetdesetih let sprožil val stečajev podjetij, začelo pa se je tudi opredeljevanje tehnoloških presežkov. Za presežek delovne sile je bila značilna predvsem njegova izobrazbena in poklicna neustreznost ter »neuporabnost« delovnih izkušenj, ki ne ustrezajo spremenjenim delovnim zahtevam ter novim, posodobljenim tehnologijam.

Na val brezposelnosti je bil RZZ dokaj nepripravljen. Dotedanji pristopi k obravnavanju brezposelnih so postali neučinkoviti.

Dejstvo, da izguba dela pomeni izgubo možnosti samopotrjevanja, samospoštovanja, socialno izolacijo, osebne in družinske probleme, pomanjkanje denarja, je narekovalo nujnost hitrejšega, predvsem pa drugačnega, ukrepanja RZZ, predvsem glede skupinske obravnave posameznih tem.

Zaradi kopičenja problemov je brezposelna oseba namreč sčasoma pri reševanju problema vse manj aktivna in se umika v pasivnost, $\mathrm{s}$ tem pa prehaja $\mathrm{v}$ dolgotrajno brezposelnost.

Navedena spoznanja so RZZ spodbudila k oblikovanju programov pomoči pri iskanju zaposlitve, namenjenih motiviranju posameznika za lastno reševanje brezposelnosti in aktivno ter učinkovito nastopanje na trgu dela.

RZZ in Ministrstvo za delo, družino in socialne zadeve sta že leta 1991 financirala pripravo programa delavnice Poti do dela in zaposlitve, izdelavo metodološkega priročnika ter usposabljanje moderatorjev programa.

\section{Cilii programa}

Splošni cilji programa so:

- motivacija brezposelnih oseb za aktiven pristop k reševanju problema brezposelnosti;

- povečanje njihove samozavesti in s tem premik iz stanja pasivnosti;

- seznanitev udeležencev s prvinami učinkovitega nastopanja na trgu dela.

Operacionalizirani cilji programa so:

- seznanitev brezposelnih oseb z zakonitostmi delovanja trga dela, $\mathrm{z}$ razmerjem med ponudbo in povpraševanjem;

- ugotoviti, kaj lahko posameznik ponudi delodajalcu (katero znanje, delovne izkušnje, interese itd.), in ugotoviti manjkajoče znanje za uspešen nastop na trgu dela;

- spoznati vire iskanja zaposlitve oziroma zaposlitvenih možnosti; 
- spoznati prvine učinkovite predstavitve delodajalcu (telefon, pisna ponudba, zaposlitveni pogovor);

- napisati pisno ponudbo.

\section{Ciljna skupina}

Delavnica je namenjena iskalcem zaposlitve vseh zahtevnostnih stopenj, ki želijo aktivno iskati zaposlitev, a ne vedo, kako pristopiti k temu.

\section{Vsebina programa}

Teme, ki jih udeleženci v skupini obravnavajo, so naslednje:

- seznanitev udeležencev z vsebino, načinom dela in urnikom;

- predstavitev udeležencev in njihovih pričakovanj ter lastna ocena možnosti zaposlitve na primernem delovnem mestu;

- zakonitosti trga delovne sile (udeleženci z moderatorjem izdelajo preglednico ponudbe in povpraševanja);

- ocenitev lastnih sposobnosti in možnosti za načrtovanje poklicne poti;

- povečanje zaposlitvenih možnosti (udeleženci izdelajo osebni zaposlitveni vzorec);

- možnosti informiranja o delovnih mestih (z uporabo metode »brain storming « udeleženci sami razmišljajo o teh možnostih);

- načini najustreznejše ponudbe na trgu delovne sile (udeleženci izdelajo pisno ponudbo in $\mathrm{z}$ metodo igre vlog preizkusijo zaposlitveni pogovor);

- opredelitev nadaljnjih aktivnosti za reševanje problema brezposelnosti.

Program traja dva dni po pet šolskih ur. Program je po osnovni obliki dela delavnica (workshop), ki temelji na načelih skupinskega dela, ob hkratnem zagotavljanju individualnega pristopa $\mathrm{k}$ vsakemu posameznemu članu skupine.

Za dosego zastavljenih ciljev je v skupini nujno ugodno ozračje, zato je treba upoštevati naslednje dejavnike:

- vodenje skupine, ki spodbuja udeležence k razmišljanju, razpravi, ustvarjalnosti in ukrepanju;

- prijazno in udobno okolje, v katerem skupina dela;

- medsebojno poznavanje udeležencev;

- jasno določen namen srečanja, jasna pravila skupnega dela in sprejet urnik dela;

- hitrost dela, ki je prilagojena skupini, spremljanje in preverjanje počutja udeležencev;

- preverjanje in potrjevanje doseženih posameznih ciljev.

Pri oblikovanju skupin se upošteva stopnja strokovne izobrazbe udeležencev, zato so ti le »grobo« razporejeni (od I. do IV. zahtevnostne stopnje in od V. do VII. stopnje). V skupini je lahko največ petnajst udeležencev, za učinkovito skupinsko delo in zagotavljanje individualnega pristopa pa je najustreznejša skupina, ki ima od najmanj 8 do največ 12 udeležencev.

Po končani delavnici napiše moderator svetovalcu za zaposlitev, zaradi lažje nadaljnje obravnave iskalca, poročilo o vsakem udeležencu.

RZZ spremlja potek delavnic z anketami in občasnimi srečanji $\mathrm{z}$ izvajalci in moderatorji delavnic.

Mentorstvo pri uvajanju novih moderatorjev prevzemajo strokovno usposobljeni mentorji RZZ. S tem skrbi RZZ za enoten in strokoven potek delavnic.
Delo $\mathrm{z}$ iskalci zaposlitve $\mathrm{v}$ skupini je pokazalo določene prednosti pred individualnimi metodami obravnave, predvsem zato, ker je taka strokovna pomoč dostopna večjemu številu brezposelnih. Udeleženci $v$ skupini dobijo, z izmenjavanjem izkušenj, spodbude za aktivnejše osebno sodelovanje pri iskanju dela in poklicnem izpopolnjevanju. Pomembno je tudi spoznanje, da v brezposelnosti niso sami.

V letošnjem letu smo na RZZ izvedli tudi evalvacijo tega programa. Zanimalo nas je, ali smo z delavnico, ki spodbuja razvoj posameznikovih zmogljivosti, in s tem omogoča učinkovit nastop na trgu dela, dosegli želene učinke.

V raziskavo smo vključili vzorec udeležencev delavnic v letih 1993-1994. Udeleženci so imeli večinoma daljšo čakalno dobo (na RZZ so bili prijavljeni v povprečju več kot šest mesecev).

Rezultati večinoma potrjujejo naša pričakovanja:

- iskalci zaposlitve so premalo aktivni, sami sicer želijo narediti čim več za rešitev svoje brezposelnosti, vendar ne vedo, kako se lotiti problema;

- brezposelni si le redko sami poiščejo informacije o možnostih vključevanja v izobraževalne programe in o njihovih vsebinah, to kaže na potrebo po vključevanju v tovrstne programe;

- po vključitvi v delavnico opažamo, da so udeleženci pri iskanju zaposlitve bolj samoiniciativni;

- udeleženci so bolj zainteresirani za dodatno izobraževanje;

- udeleženci so zadovoljni z vsebinami delavnice in menijo, da so posamezne vsebine za njih koristne;

- tudi organizacijo in časovno opredelitev delavnice ocenjujejo kot primerno;

- svetovalci zaposlitve opažajo večjo dejavnost udeležencev pri vključevanju v programe zavoda in pri iskanju zaposlitve;

- učinki se kažejo tudi v kvalitetnejši komunikaciji med stranko in svetovalcem zaposlitve;

- udeleženci se po delavnici pogosteje vključujejo v programe RZZ;

- zaposli se jih približno polovica, od vključitve v delavnico do realizacije zaposlitve traja povprečno osem mesecev.

Glede na učinke programa se nam zdi smiselno, da bi ta program izvajali tudi $\mathrm{v}$ prihodnje. Večini iskalcev zaposlitve namreč primanjkuje teoretičnega in praktičnega znanja o tem, kako iščemo zaposlitev. Tega, žal, ne uči nobena šola. Mnogim brezposelnim se zdi, da so v brezizhodnem položaju. Dokazati jim je treba, da to ni res, da si brezizhodnost le domišljajo in da je brezposelnost pravzaprav lahko preizkušnja, ki pelje v novo kvalitetnejšo obdobje posameznikovega življenja in dela. Za gotovo pa drži, da je treba najprej kaj storiti, šele nato sklepati.

Posameznik mora najprej spoznati, da si svojo usodo kroji sam in s tem prevzema lastne pobude in odgovornost za svojo prihodnost. Ob prehodu v, za nas novi, tržni sistem, mora postati vsakemu jasno, da njegovih problemov ne bodo reševali drugi, kot je bila večina ljudi navajena do sedaj, ampak da bo treba spremeniti način razmišljanja. S programi, kot je delavnica Poti do dela in zaposlitve, poskušamo iskalcem zaposlitve takšen način razmišljanja tudi približati.

Dušanka Lužar

dipl. pedagoginja, Zavod za zaposlovanje Maribor 